\title{
In vitro Monitoring of Macro and Microelements in Multimineral Preparations across Dissolution Profiles by Inductively Coupled Plasma Optical Emission Spectrometry (ICP OES)
}

\author{
Aníbal de F. Santos Júnior, ${ }^{*, a, b}$ Ramon R. Sá, ${ }^{a}$ Laiana O. B. Silva, ${ }^{b}$ \\ Hemerson I. F. Magalhães, ${ }^{c}$ Taiana B. Tarantino ${ }^{d}$ and Maria Graças A. Korn ${ }^{d}$ \\ ${ }^{a}$ Departamento de Ciências da Vida and ${ }^{b}$ Departamento de Ciências Exatas e da Terra, \\ Universidade do Estado da Bahia, 41195-000 Salvador-BA, Brazil \\ 'Departamento de Ciências Farmacêuticas, Universidade Federal da Paraíba, \\ 58051-900 João Pessoa-PB, Brazil \\ ${ }^{d}$ Instituto de Química, Universidade Federal da Bahia, Campus Ondina, \\ 40170-290 Salvador-BA, Brazil
}

\begin{abstract}
In this study, inductively coupled plasma optical emission spectrometry (ICP OES) was used for multi-element analysis in five multimineral preparations from a dissolution test, in accordance with the United States Pharmacopeia (USP 34 method): apparatus 1, $75 \mathrm{rpm}$ and $900 \mathrm{~mL}$ of $0.1 \mathrm{~mol} \mathrm{~L}^{-1} \mathrm{HCl}$. Element releases in all samples (minimum-maximum in \%) were: $\mathrm{Ca}(14.5-28.2)$, $\mathrm{Cr}$ (54.5-68.0), Cu (2.9-10.0), Fe (4.0-34.3), Mg (6.0-25.2), Mn (2.6-51.2), V (0.0-51.4) and $\mathrm{Zn}$ (1.5-107.3). The concentrations of $\mathrm{Al}, \mathrm{Ba}, \mathrm{Cd}, \mathrm{Co}, \mathrm{Mo}, \mathrm{Pb}$ and $\mathrm{Se}$ were below the limit of detection of ICP OES. Accuracy was assessed by microwave digestion and recovery values of 94-102\%. USP 34 method indicates that not less than $75 \%$ of the elements described on the product label must be dissolved in $1 \mathrm{~h}$. Only the release of $\mathrm{Zn}$ met the recommendations. The results indicated the need for greater quality control in multivitamin preparations. The dissolution test was validated in order to contribute to Brazilian and other pharmacopoeias.
\end{abstract}

Keywords: multimineral, multivitamin preparations, dissolution profiles, ICP OES

\section{Introduction}

The concern about medicine quality has been growing and led the pharmaceutical industry to research, develop and control medicine production, across reliable and effective analytical methods in order to guarantee the quality control of these products. Dissolution tests evaluate the quality of a drug product; obtain the dissolution profile of a drug from a dosage form; identify formulations that present a potential hazard to drug bioavailability and serve as a useful tool in the development of formulations. ${ }^{1,2}$ Dissolution tests predict in vitro bioequivalence (BE) of a drug. The obtention and comparison of dissolution profiles are important tools for establishing the similarity of pharmaceutical forms containing the active principle of interest. ${ }^{3-6}$

Mineral absorption by living organisms is a dynamic and complex process, dependent on several factors,

*e-mail: afjunior@uneb.br including levels of ingested element, age, gastrointestinal $\mathrm{pH}$, environmental conditions, nutritional status, element disabled or not, the presence of antagonistic minerals or other nutrients. ${ }^{7}$ The consumption of food supplements containing vitamins and minerals has increased considerably in recent decades. Dietary supplements or nutritional products contain vitamins, minerals, herbal products, tissue extracts, proteins and amino acids and other products, and are consumed with the goal of improving health, physical performance and prevent diseases. ${ }^{8,9}$

Multivitamin and multimineral preparations in solid pharmaceutical forms (tablets, caplets and capsules) contain the following nutrients: vitamin A, complex-B, C, D, E, K and minerals such as magnesium, zinc, calcium, iodine, selenium, copper, manganese, chromium, molybdenum and others. ${ }^{10,11}$ Depending on the chemical form and production conditions, different products may release these substances erratically, affecting absorption. Therefore, in vitro monitoring of the release of these minerals into 
multivitamin supplements is important in assessing quality and ensuring patient safety. ${ }^{12,13}$

Inductively coupled plasma optical emission spectrometry (ICP OES) is an analytical technique widely used for the determination of trace metals in biological samples since it has good quantitative multi-element capability, wide linear dynamic ranges, good sensitivity and versatility, limited spectra and chemical interferences, low limits of detection (LOD) and quantification (LOQ), speed analysis and reasonable cost. ${ }^{14,15}$ In the literature, there is a crescent number of studies describing the drug determination and pharmaceutical formulations by several analytical methods, however mineral determination in multivitamins preparations is scarce. ${ }^{16-21}$

This study aims to propose a method for determination of macro and trace elements in multimineral and multivitamin preparations across dissolution profiles using ICP OES.

\section{Experimental}

\section{Samples, reagents and solutions}

The samples of the multivitamin and multimineral tablets were adquired from local drugstores in the city of Salvador, Bahia State, Brazil. All samples were kept in the original package until the execution of the experiments. The tablets used for dissolution test, quantification and comparison of profiles were (the formulations did not contain excipients, according to the label):

(i) product $\mathrm{A}$ - labeled to contain Ca: $162 \mathrm{mg}$; $\mathrm{Cu}: 2 \mathrm{mg}$; Cr: $25 \mu \mathrm{g}$; Sn: $10 \mu \mathrm{g}$; Fe: 18 mg; Mg: 100 mg; Mn: 2.5 mg; Mo: $25 \mu \mathrm{g}$; Ni: $5 \mu \mathrm{g}$; Se: $25 \mu \mathrm{g}$; K: $80 \mathrm{mg}$; Si: $2 \mathrm{mg}$; V: $10 \mu \mathrm{g}$; Zn: 15 mg; I: $150 \mu g$; vitamin A: 5000 UI; vitamin E: 30 UI; vitamin C: $60 \mathrm{mg}$; pantothenic acid: $10 \mathrm{mg}$; folic acid: $400 \mu$ g; biotin: $30 \mathrm{mg}$; vitamin B12: $6 \mu \mathrm{g}$; vitamin B6: $2 \mathrm{mg}$; vitamin D3: 400 UI; vitamin K1: $25 \mu \mathrm{g}$ : vitamin B1: $1.5 \mathrm{mg}$ : vitamin B2: $1.7 \mathrm{mg}$ and nicotinamide: $20 \mathrm{mg}$;

(ii) product B - labeled to contain Ca: $51.3 \mathrm{mg}$; $\mathrm{Mg}: 21.2 \mathrm{mg}$; Fe: $10 \mathrm{mg}$; $\mathrm{Mn}: 0.5 \mathrm{mg}$ : $\mathrm{Cu}: 1.0 \mathrm{mg}$; $\mathrm{Zn}: 0.5 \mathrm{mg}$ : Mo: $0.1 \mathrm{mg}$; vitamin A: $10000 \mathrm{UI}$; vitamin B1: $20 \mathrm{mg}$ : vitamin B2: $5 \mathrm{mg}$; nicotinamide: $50 \mathrm{mg}$; vitamin B6: $10 \mathrm{mg}$ : vitamin B5: $11.6 \mathrm{mg}$; biotin: $0.25 \mathrm{mg}$; vitamin B12: $5 \mathrm{mg}$; vitamin C: $150 \mathrm{mg}$; vitamin D: $500 \mathrm{UI}$; vitamin E: $10 \mathrm{mg}$; (iii) product C - labeled to contain $\mathrm{Ca}: 50 \mathrm{mg}$; $\mathrm{Cu}: 0.5 \mathrm{mg}$; Fe: $50 \mathrm{mg}$; Mg: $5 \mathrm{mg}$; Mn: $3 \mathrm{mg}$; K: $10 \mathrm{mg}$; Zn: $2 \mathrm{mg}$; F: $0.04 \mathrm{mg}$; vitamin B5: $5 \mathrm{mg}$;

(iv) product D - labeled to contain $\mathrm{Mg}$ : $12.5 \mathrm{mg}$; $\mathrm{Zn}: 15 \mathrm{mg}$; Cr: $25 \mu \mathrm{g}$; Se: $12.5 \mu \mathrm{g}$; Mn: $2.5 \mathrm{mg}$; Cu: $0.125 \mathrm{mg}$; vitamin A: $2500 \mathrm{UI}$; vitamin C: $250 \mathrm{mg}$; vitamin E: $100 \mathrm{UI}$; (v) product $\mathrm{E}$ (pediatric formulation) - labeled to contain
Ca: $50 \mathrm{mg}$; Mg: $36.5 \mathrm{mg} ;$ Fe: $3 \mathrm{mg}$; Zn: $2.55 \mathrm{mg}$; Se: $10.5 \mathrm{mg}$; Mo: $11 \mu \mathrm{g}$; Cr: $7.5 \mu \mathrm{g}$; Mn: 0.75 mg; Cu: $220 \mu \mathrm{g}$.

Ultrapure water (resistivity $18 \mathrm{M} \Omega \mathrm{cm}$, Milli-Q Pluswater purification system, Millipore Molsheim, France) was used to prepare all standard and sample solutions. All labwares were soaked in a $10 \%\left(\mathrm{v} \mathrm{v}^{-1}\right) \mathrm{HNO}_{3}$ solution bath for $24 \mathrm{~h}$, rinsed with high-purity water and dried under clean-air conditions at room temperature.

Working solutions were prepared from stock solutions containing $1000 \mathrm{mg} \mathrm{L}^{-1}$ of Al, Ba, Ca, Cd, Cu, Co, Cr, Fe, $\mathrm{Mg}, \mathrm{Mn}, \mathrm{Mo}, \mathrm{Ni}, \mathrm{Pb}, \mathrm{Se}, \mathrm{V}$ and $\mathrm{Zn}$ (Merck, Germany). The solutions were prepared from reference stock solutions of the various metallic cations, from rates and appropriate dilutions necessary to prepare the multi-element reference solution with a final concentration ranging from 10.0 to $50.0 \mathrm{mg} \mathrm{L}^{-1}$. The solutions were stored in polyethylene bottles previously decontaminated. All chemicals were of analytical grade with no further purification. Hydrochloric acid $(\mathrm{HCl})$ was purchased from Quimex ${ }^{\circledR}$ (Merck, Brazil).

Instrumentation

The total acid digestion of multivitamin and multimineral samples was realized by commercial high-pressure laboratory microwave oven (Milestone Ethos 1600 Microwave Labstation, Sorisole, Italy) with frequency of $2450 \mathrm{~Hz}$ and energy output of $900 \mathrm{~W}$. This microwave digestion system was equipped with ten 100-mL tetrafluoromethoxy vessels and a ceramic vessel jacket. The maximum operating temperature, power and pressure were $180{ }^{\circ} \mathrm{C}, 1000 \mathrm{~W}$ and $100 \mathrm{bar}$, respectively, for $30 \mathrm{~min}$.

The dissolution test was performed in a dissolution test apparatus Nova Ética (Model 299, Brazil) multibath $(n=6)$, in accordance with the United States Pharmacopoeia (USP 34) general methods. ${ }^{3}$

An inductively coupled plasma optical emission spectrometer with axially-viewed configuration (ICP OES, Vista-PRO, Varian, Mulgrave, Australia) was used for multi-element determinations. The system is equipped with a simultaneous charge-coupled device (CCD) solid-state detector that allows the measurements (167 to $785 \mathrm{~nm}$ ). Pre-optical systems and the polychromator $\left(34^{\circ} \mathrm{C}\right)$ were purged with argon. To provide a wide linear dynamic range, minimize interferences and obtain low background, an end-on gas interface was used. All emission signals were integrated according to line intensities and analyte concentrations. The wavelengths of the analytical lines were selected considering the most prominent line and, alternatively, secondary lines were used to prevent possible 
interferences. All analyses were performed in triplicate. Optimized operating parameters and analytical wavelengths are listed in Table 1.

Table 1. Parameters optimized for element determination by ICP OES

\begin{tabular}{lc}
\hline Instrumental parameter & ICP optimum condition \\
\hline RF generator power / W & 1300 \\
Plasma gas rate / $\left(\mathrm{mL} \mathrm{min}^{-1}\right)$ & 15.0 \\
Auxiliary gas rate / $\left(\mathrm{mL} \mathrm{min}^{-1}\right)$ & 1.5 \\
Nebulizer gas rate / $\left(\mathrm{mLmin}^{-1}\right)$ & 0.7 \\
Sample uptake rate / $\left(\mathrm{mL} \mathrm{min}^{-1}\right)$ & 0.8 \\
Replicate & 3 \\
Injector tube diameter / $\mathrm{mm}_{\text {Signal integration time / s }}$ & 2.4 \\
\hline
\end{tabular}

Analytical wavelength / $\mathrm{nm}$

Al I 396.152; Ba I 455.403; Ca II 396.847; Cd I 228.802; Co I 238.892; Cr II 267.716; Cu I 324.754; Fe II 238.204;

Mg II 279.553; Mn II 257.610; Mo I 202.032; Ni II 227.021; Pb I 217.000; Se I 196.026; V I 309.310; Zn II 213.857

I: Atomic emission line; II: ion emission line/nebulizer type concentric, sea spray/spray chamber cyclone type.

\section{Dissolution test conditions}

The dissolution testing was performed in accordance with the United States Pharmacopoeia (USP 34 method) testing apparatus 1 (basket) rotating at $75 \mathrm{rpm}$ and $900 \mathrm{~mL}$ dissolution medium $\left(0.1 \mathrm{~mol} \mathrm{~L}^{-1} \mathrm{HCl}\right)$ maintained at $37.0 \pm 0.5{ }^{\circ} \mathrm{C}$ for $1 \mathrm{~h}^{3}$ Manual sampling aliquots of $10.0 \mathrm{~mL}$ were removed at $5,10,15,20,30,40,50,60$ and 90 min after dissolution optimization, and analyzed by ICP OES. The replacement of the same volume of the medium at $37 \pm 0.5^{\circ} \mathrm{C}$ was performed for constant volume maintenance.

\section{Validation studies}

The proposed dissolution test was validated through the analysis of linearity, precision and accuracy parameters. ${ }^{3,22-24}$

The multi-element solution stability and samples were evaluated for $24 \mathrm{~h}$ at room temperature and kept at $37^{\circ} \mathrm{C}$ for $2 \mathrm{~h}$ in 0.01 and $0.1 \mathrm{~mol} \mathrm{~L}^{-1} \mathrm{HCl}$ by checking changes in the analytical signal after the analysis by ICP OES.

Aliquots of $100.0 \mu \mathrm{g} \mathrm{mL} \mathrm{m}^{-1}$ multi-element solution of $\mathrm{Al}, \mathrm{As}, \mathrm{Ba}, \mathrm{Ca}, \mathrm{Cd}, \mathrm{Cr}, \mathrm{Co}, \mathrm{Cu}, \mathrm{Fe}, \mathrm{Mg}, \mathrm{Mn}, \mathrm{Ni}, \mathrm{Pb}, \mathrm{Se}$, $\mathrm{V}$ and $\mathrm{Zn}$ reference standard, prepared with $0.1 \mathrm{~mol} \mathrm{~L}^{-1}$ $\mathrm{HCl}$, were transferred to volumetric flasks to obtain the final concentrations of 1.0, 5.0, 15.0, 20.0, 25.0, 30.0, 40.0 and $50.0 \mu \mathrm{g} \mathrm{mL}^{-1}$. Each solution was prepared in triplicate. The linearity was evaluated by linear regression and a good linearity was obtained for all the observed lines (with correlation coefficient $\left(\mathrm{R}^{2}\right)$ in the range of 0.9995-0.9999).

Repeatability and intermediate precision were used to evaluate the precision of the method. Repeatability expresses the precision under the same operating conditions over a short time interval. The repeatability was evaluated through relative standard deviation (RSD) from the obtained data, at two different moments of analysis, in the same day. The precision was evaluated by analyzing solutions of macro and microelements with a working concentration of $5 \mu \mathrm{g} \mathrm{mL}^{-1}$ in six replicates. The intermediate precision was obtained by comparing the values obtained using ICP OES acquired in two different days, one day with analyst change.

A recovery study was conducted by adding known amounts $(5 \mu \mathrm{g})$ of each mineral. The dissolution test was performed for $60 \mathrm{~min}$ using $900 \mathrm{~mL}$ of dissolution medium $0.1 \mathrm{~mol} \mathrm{~L}^{-1} \mathrm{HCl}$, apparatus 1 rotating at $75 \mathrm{rpm}$. Aliquots of $10.0 \mathrm{~mL}$ were filtered and analyzed by ICP OES. Each concentration was prepared and introduced to the nebulizer, in triplicate.

In addition, the accuracy of the analytical method was attested by analysis of multimineral preparations and certified reference material, furnished by National Institute of Standard and Technology (Gaithersburg, MD, USA), spinach leaves NIST 1570a. The materials, approximately $300 \mathrm{mg}$, were directly inserted into a microwave-closed vessel. ${ }^{25} 1 \mathrm{~mL}$ of $30 \%\left(\mathrm{~m} \mathrm{~m}^{-1}\right) \mathrm{H}_{2} \mathrm{O}_{2}$ and $7.0 \mathrm{~mL}$ of $\mathrm{HNO}_{3}$ solutions were added to each vessel, and operating conditions of the microwave digestion system were optimized. ${ }^{16}$ Blanks were prepared in each sample batch. All experiments were performed in triplicate. The resulting solutions were analyzed by ICP OES.

The figures of merit for each procedure were evaluated based on the LOD and LOQ values under robust ICP OES conditions. ${ }^{26}$ The LOD values were calculated using the concentration equivalent to three times the standard deviation $(3 \sigma)$ of the signal $(n=10)$ of the reagent blank solution, and the LOQ values were calculated using the $10 \sigma$ criterion $(n=10)$.

Dissolution profiles were obtained at test conditions described above. Aliquots of $10.0 \mathrm{~mL}$ were withdrawn from each vessel and the same volume of the dissolution medium was replaced to maintain a constant total volume. The selected times were $0,1,2,3,4,5,10,12,15,18$, $20,22,25,30,35,40,45,50,55,60,65,70,75,80,85$ and $90 \mathrm{~min}$. Twenty six samples were analyzed for each dissolution profile. The withdrawn aliquots were first filtered and analyzed by ICP OES. 
The statistical analysis was performed using the principal component analysis (PCA) (by software Statistica 7.0) and the Student's $t$-test to verify significant differences between the values obtained by the proposed method and the certified values for analytes.

\section{Results and Discussion}

\section{Analytical performance}

The accuracy of the determinations was attested by the analysis of spinach leaves, certified reference material (CRM 1570a). The results (Table 2) demonstrated good agreement with the reference values of the CRM sample for $\mathrm{Cd}, \mathrm{Cu}, \mathrm{Mn}, \mathrm{Ni}$ and Zn. Applying Student's $t$-test (with 95\% confidence), it was concluded that there is no significant difference (except for $\mathrm{Zn}$ ) between the values obtained by the proposed method and the certified value, which gives accuracy to the method.

Table 2. Analysis of CRM 1570a (spinach leaves) by ICP OES after microwave radiation procedures (mean \pm standard deviation, $\mathrm{n}=3,95 \%$ confidence level)

\begin{tabular}{lccc}
\hline Element & $\begin{array}{c}\text { Achieved value / } \\
\left(\mu \mathrm{g} \mathrm{g}^{-1}\right)\end{array}$ & $\begin{array}{c}\text { Certified value / } \\
\left(\mu \mathrm{g} \mathrm{g}^{-1}\right)\end{array}$ & Recovery / \% \\
\hline $\mathrm{Cd}$ & $2.72 \pm 0.12$ & $2.89 \pm 0.07$ & 94.1 \\
$\mathrm{Cu}$ & $12.3 \pm 0.05$ & $12.2 \pm 0.60$ & 100.8 \\
$\mathrm{Mn}$ & $75.6 \pm 0.80$ & $75.9 \pm 1.90$ & 99.6 \\
$\mathrm{Ni}$ & $2.12 \pm 0.06$ & $2.14 \pm 0.10$ & 99.1 \\
$\mathrm{Zn}$ & $83.7 \pm 0.15$ & $82.00 \pm 3.00$ & 102.1 \\
\hline
\end{tabular}

To perform the recovery test, $5 \mu \mathrm{g}$ of each analyte were added to a randomly selected multivitamin sample (sample A). The obtained recovery values (in the range of 94 to $102 \%$ ) showed that there is no loss during the process. The precision was assessed and the RSD values lower than $2 \%$ indicated the good precision of this method.

The LOD and LOQ values were obtained for $\mathrm{Ca}, \mathrm{Cd}$, $\mathrm{Co}, \mathrm{Cr}, \mathrm{Cu}, \mathrm{Fe}, \mathrm{Mg}, \mathrm{Mn}, \mathrm{Ni}, \mathrm{Pb}, \mathrm{Se}, \mathrm{V}$ and $\mathrm{Zn}$ determined by ICP OES (Table 3), and are comparable to those reported in the literature to determine minerals in multivitamin preparations.

\section{Optimization of ICP OES parameters}

The optimization of the operational parameters of ICP OES is an essential step for the execution of the analyses since the intensities and shapes of the element signals depend on the matrix. ${ }^{27}$ Multivitamin preparations are complex samples, and this optimization step is essential. In this study, the radiofrequency (RF) incident power and the nebulizer argon gas flow rate were optimized using multimineral and multivitamin preparation matrices, aqueous standard and standard additions. The RF incident power was studied and optimized in the range of $1000-1400 \mathrm{~W}$. The results indicated that the plasma stability, sensitivity and linearity were satisfactory at $1300 \mathrm{~W}$ for almost all the analytes. The effect of nebulizer argon gas flow rate was studied from 0.60 to $0.90 \mathrm{~L} \mathrm{~min}^{-1}$. A $0.70 \mathrm{~L} \mathrm{~min}^{-1}$ nebulizer argon gas flow rate was adopted, providing high sensitivity and good precision. The optimum values for all studied parameters are presented in Table 1.

To assess the linearity, calibration curves for the minerals (Al, As, Ba, Ca, Cd, Cr, Co, Cu, Fe, Mg, Mn, Ni, $\mathrm{Pb}, \mathrm{Se}, \mathrm{V}$ and $\mathrm{Zn}$, prepared with $0.1 \mathrm{~mol} \mathrm{~L}^{-1} \mathrm{HCl}$ ) were constructed, plotting concentration $\left(\mu \mathrm{g} \mathrm{mL}^{-1}\right) v s$. analytical signal by ICP OES. The linearity was demonstrated because a correlation coefficient of approximately 0.9997 was obtained at the studied concentration range (1.0 to $50.0 \mu \mathrm{g} \mathrm{mL}^{-1}$ ). Matrix interferences were evaluated. However, the absence of this effect is observed under the selected operating conditions since there were no significant differences (95\% confidence level) in the slopes of the calibration curves of the analyzed elements.

\section{Dissolution study and analytical application in multivitamin tablets}

The Brazilian Pharmacopoeia does not indicate a methodology for mineral dissolution tests, in oral solid dosage forms. ${ }^{22}$ The dissolution test conditions were selected based on a screening study with USP 34 apparatus 1 (baskets) at $75 \mathrm{rpm}$, in $900 \mathrm{~mL}$ of $0.1 \mathrm{~mol} \mathrm{~L}^{-1}$ $\mathrm{HCl}$. USP 34 indicates that not less than $75 \%$ of the elements described on the product label must be dissolved

Table 3. Limits of detection (LOD) and of quantification (LOQ) for macro and microelements determined by ICP OES after the microwave radiation (MW) procedure

\begin{tabular}{|c|c|c|c|c|c|c|c|c|c|c|c|c|c|}
\hline \multirow[b]{2}{*}{ Element } & \multicolumn{13}{|c|}{ Microwave radiation (wet digestion) procedure } \\
\hline & $\begin{array}{c}\mathrm{Ca} / \\
\left(\mathrm{mg} \mathrm{L}^{-1}\right)\end{array}$ & $\begin{array}{c}\mathrm{Cd} / \\
\left(\mu \mathrm{g} \mathrm{L}^{-1}\right)\end{array}$ & $\begin{array}{c}\mathrm{Co} / \\
\left(\mu \mathrm{g} \mathrm{L}^{-1}\right) \\
\end{array}$ & $\begin{array}{c}\mathrm{Cr} / \\
\left(\mu \mathrm{g} \mathrm{L} \mathrm{L}^{-1}\right)\end{array}$ & $\begin{array}{c}\mathrm{Cu} / \\
\left(\mu \mathrm{g} \mathrm{L}^{-1}\right)\end{array}$ & $\begin{array}{c}\mathrm{Fe} / \\
\left(\mu \mathrm{g} \mathrm{L}^{-1}\right)\end{array}$ & $\begin{array}{c}\mathrm{Mg} / \\
\left(\mathrm{mg} \mathrm{L}^{-1}\right)\end{array}$ & $\begin{array}{c}\mathrm{Mn} / \\
\left(\mu \mathrm{g} \mathrm{L}^{-1}\right)\end{array}$ & $\begin{array}{c}\mathrm{Ni} / \\
\left(\mu \mathrm{g} \mathrm{L}^{-1}\right)\end{array}$ & $\begin{array}{c}\mathrm{Pb} / \\
\left(\mu \mathrm{g} \mathrm{L}^{-1}\right)\end{array}$ & $\begin{array}{c}\mathrm{Se} / \\
\left.(\mu \mathrm{g} \mathrm{L})^{-1}\right)\end{array}$ & $\begin{array}{c}\mathrm{V} / \\
\left(\mu \mathrm{g} \mathrm{L}^{-1}\right) \\
\end{array}$ & $\begin{array}{c}\mathrm{Zn} / \\
\left(\mu \mathrm{g} \mathrm{L} \mathrm{L}^{-1}\right)\end{array}$ \\
\hline LOD & 0.37 & 0.10 & 0.16 & 0.23 & 0.35 & 0.15 & 0.08 & 0.02 & 0.47 & 0.39 & 0.31 & 0.44 & 0.10 \\
\hline LOQ & 1.23 & 0.34 & 0.53 & 0.77 & 1.17 & 0.52 & 0.27 & 0.07 & 1.56 & 1.29 & 1.03 & 1.47 & 0.36 \\
\hline
\end{tabular}


in $1 \mathrm{~h} .{ }^{3}$ Several factors may influence the outcome of that test, such as friability, the nature of the excipients, besides coating and disintegration rate. Moreover, since they are supplement multivitamins, the presence of lipo- and water-soluble vitamins may affect the release of minerals.

The analysis of the dissolution time advocated by the pharmacopoeias is very punctual and shows few data regarding the dissolution process. A multipoint analysis is extremely important to assess the behavior of the dissolution and, therefore, graphics were elaborated to evaluate the concentration of the mineral dissolved vs. time (dissolution profiles). The differences in the dissolution profiles of the analyzed products can be justified since factors such as the tablet coating (film), polymorphism and biopharmaceutical factors may influence the release of the minerals. Figure 1 shows the dissolution profiles of each product.

It was noticed that, after the withdrawal of aliquots and 90 min selected for the evaluation process, the most of the products presented in the waste basket (Figure 2). This may not result in the total release of the minerals to the reaction medium, affecting the element availability in biological fluids and, consequently, quantification and bioavailability. This fact can be explained by technological
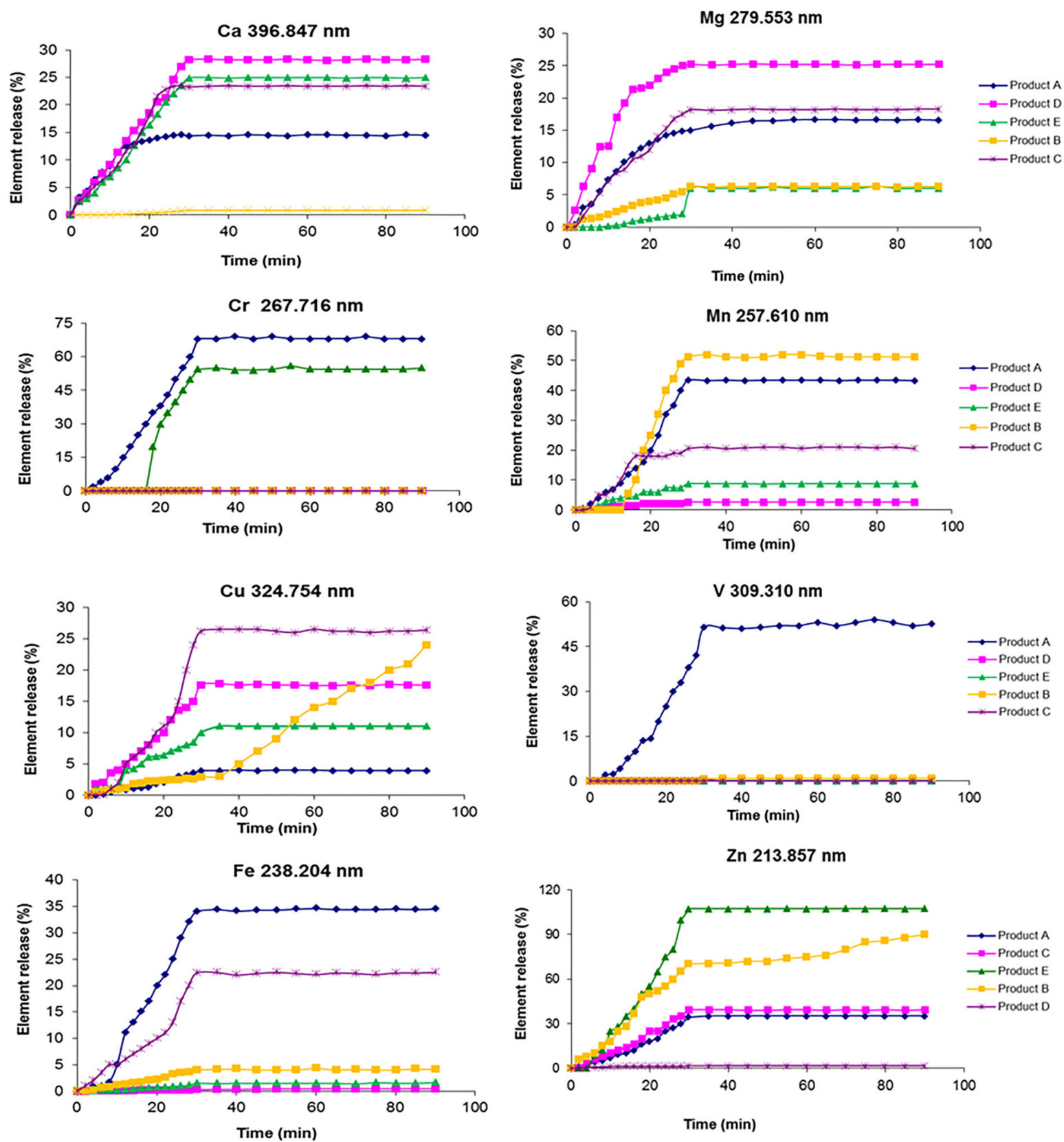

Figure 1. Dissolution profiles for $\mathrm{Ca}, \mathrm{Cr}, \mathrm{Cu}, \mathrm{Fe}, \mathrm{Mg}, \mathrm{Mn}, \mathrm{V}$ and $\mathrm{Zn}$ in multivitamin and multimineral preparations after analysis by ICP OES. 
production factors, in which poorly soluble excipients are added, besides compressive strength and the way in which minerals are connected to other components of the formulation.

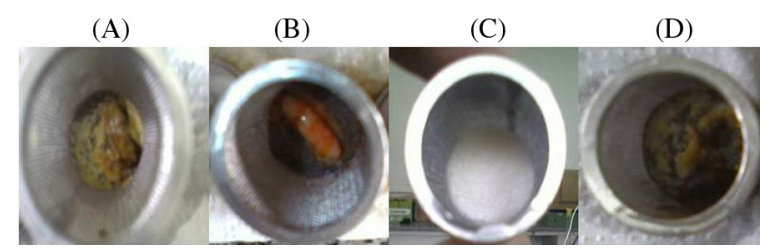

Figure 2. Waste products (A, B, C and D) of the basket dissolutor observed after 90 min of dissolution.

The dissolution profiles for Ca were similar. After 2 min, the release of this element was already evident. However, it was observed that the analyzed products released $\mathrm{Ca}$ in the range of 14.5 to $28.2 \%$. This fact implies in a lower element availability in the organism to be absorbed. The release of this element is very important since it is a macronutrient useful in physiological systems (muscular, bone, blood, etc.). ${ }^{28}$ The label of product $\mathrm{D}$ does not report the presence of $\mathrm{Ca}$ in its formulation.

Magnesium is required for nucleic acids in protein synthesis and human reproduction..$^{29}$ The dissolution profiles for $\mathrm{Mg}$ showed a release range of up to $30 \mathrm{~min}$ of testing for this element. After this time, the profiles presented similar formats, however, releasing different amounts of this element (6.0 to $25.2 \%$ ).

Chromium(III) is important for nucleic acid synthesis, growth, thyroid metabolism, glycemic control and as a cofactor for numerous enzymatic reactions, while chromium(VI) may be carcinogenic. ${ }^{30}$ The dissolution profiles for $\mathrm{Cr}$ showed significant differences, especially with regard to product $\mathrm{E}$ since any $\mathrm{Cr}$ content present in the product just begins to be released after $30 \mathrm{~min}$. This suggests that $\mathrm{Cr}$ is protected in the array and is then gradually released. Further, it was observed that products $\mathrm{C}$ and $\mathrm{D}$ released minimum quantities of $\mathrm{Cr}$. However, this element is not declared on the label, suggesting possible contamination of pharmaceutical forms.

The dissolution profiles for $\mathrm{Cu}$ showed small differences, except for product $\mathrm{B}$, which presented an increase in the dissolution profile for this element. Products D and E were those with the lowest concentrations of $\mathrm{Cu}$, having a greater release of the element after $25 \mathrm{~min}$. By $20 \mathrm{~min}$, a low release of mineral in the product was observed, but, at $30 \mathrm{~min}$, the most significant release occurs. Product A showed the lowest release (of $\mathrm{Cu}$ after $90 \mathrm{~min}$ of dissolution test). The results suggest that $\mathrm{Cu}$ is difficult to release its matrix supplement, corroborating to the findings of Soriano et al..$^{20}$ These authors determined $\mathrm{Cu}, \mathrm{Fe}, \mathrm{Mn}$ and
$\mathrm{Zn}$ in multivitamin/multimineral tablets by flame atomic absorption spectrometry (F AAS) after extraction of the analytes with diluted $\mathrm{HCl}$. Copper deficiency can cause hypotonia, psychomotor retardation and hypothermia (in children) and anemia, vesical diverticula, leukopenia and bone lesions (in adults). ${ }^{31}$

The consumption of iron-based multivitamins reflects the significant importance in patients with disorders such as anemia. ${ }^{32}$ The content of Fe was very different through the dissolution profiles of the samples (4.0 to $34.3 \%$ ). The samples that most released minerals after $30 \mathrm{~min}$, if not totally, were samples A and C since they were further stated than the element labels. It was noticed that the other samples showed no significant iron levels after 90 min of testing, suggesting a pharmaceutical problem which hindered the release of the element. Further, it was observed that product D released minimum quantities of Fe. However, this element is not declared on the label, suggesting possible contamination of pharmaceutical forms.

The dissolution profiles for $\mathrm{Mn}$ were quite similar for samples A and C, especially in the first 15 min, differing up to the next $20 \mathrm{~min}$, when different amounts were released, even representing almost the same concentration of mineral labels. Perhaps, this fact is explained by the way that the metal is formed in the matrix. The profiles presented similar formats for all products, however, releasing different amounts of this element (2.6 to 51.2\%). Manganese activates the formation of aminoacids, some enzymes and is involved in the partial regulation of oxidative phosphorylation. ${ }^{33}$

Vanadium is an important element for the human body. Its lack can cause several disturbances (infertility, disturbed iron metabolism, anemia and alterations in metabolism of bones, teeth and cartilages). ${ }^{34}$ For V, present in low concentrations only in the product $\mathrm{A}$, the dissolution profiles were similar to those obtained for Cr. Product A was the only one with the presence of the component in its composition. Further, it was observed that products B, C, $\mathrm{D}$ and $\mathrm{E}$ released minimum quantities of $\mathrm{Fe}$. However, this element is not declared on the label, suggesting possible contamination of pharmaceutical forms.

Zinc acts as an enzyme cofactor and transcription factor in the human body. It is required for the synthesis of nucleic acids, growth, gene expression and regulation and immunity. ${ }^{35}$ For Zn, the dissolution profiles showed no significant differences, except for product $\mathrm{B}$, which showed an increasing dissolution profile, suggesting therefore that the metal was not satisfactorily released from the matrix. Zinc deficiency promotes growth failure and affects epidermal, gastrointestinal, central nervous, immune, skeletal and reproductive systems in human organism. ${ }^{36}$ 
Similar concentrations of $\mathrm{Zn}$ were reported by the majority of products on labels. After $30 \mathrm{~min}$, a mineral release was observed for all products (1.5 to $107.3 \%$ ).

The contents of $\mathrm{Ca}, \mathrm{Cr}, \mathrm{Cu}, \mathrm{Fe}, \mathrm{Mg}, \mathrm{Mn}, \mathrm{V}$ and $\mathrm{Zn}$ in multivitamin tablets (marketed in the city of Salvador (Bahia State, Brazil)) were determined using ICP OES $(n=3)$. Tables 4 and 5 were prepared for the visualization of the concentration values of the elements, obtained after $1 \mathrm{~h}$ of dissolution and after microwave digestion.
The contents of $\mathrm{Al}, \mathrm{Ba}, \mathrm{Cd}, \mathrm{Co}, \mathrm{Mo}, \mathrm{Ni}, \mathrm{Pb}, \mathrm{Se}$ and Sn were not quantified due to be below the LOQ values. Analyzing the results, it is clear that most of the multivitamins and minerals have not released the amount of analyte informed on the labels for the dissolution test. The listed values were those obtained after $1 \mathrm{~h}$ of dissolution, as recommended by the United States Pharmacopeia. ${ }^{3}$

Soltyk et al. ${ }^{37}$ determined the chemical elements in pharmaceutical preparations $(\mathrm{Ca}, \mathrm{Cr}, \mathrm{Cu}, \mathrm{Fe}, \mathrm{Mg}$,

Table 4. Concentrations of $\mathrm{Ca}, \mathrm{Cu}, \mathrm{Fe}, \mathrm{Mg}, \mathrm{Mn}, \mathrm{Zn}, \mathrm{Cr}$ and $\mathrm{V}$ in multimineral and multivitamin preparations, after $1 \mathrm{~h}$ of dissolution and analysis by ICP OES (mean \pm standard deviation, $\mathrm{n}=3,95 \%$ confidence level)

\begin{tabular}{|c|c|c|c|c|c|}
\hline Element & Product A & Product B & Product $\mathrm{C}$ & Product D & Product E \\
\hline $\mathrm{Ca} /\left(\mathrm{mg} \mathrm{g}^{-1}\right)-396.847 \mathrm{~nm}$ & $\begin{array}{c}28.278 \pm 4.21 \\
(14.5 \%)\end{array}$ & $\begin{array}{c}12.011 \pm 2.74 \\
(23.4 \%)\end{array}$ & $\begin{array}{c}14.110 \pm 2.46 \\
(28.2 \%)\end{array}$ & $<0.37$ & $\begin{array}{c}12.437 \pm 1.54 \\
(24.9 \%)\end{array}$ \\
\hline $\mathrm{Cr} /\left(\mu \mathrm{g} \mathrm{g}^{-1}\right)-267.716 \mathrm{~nm}$ & $\begin{array}{c}17.005 \pm 0.02 \\
(68.0 \%)\end{array}$ & $<0.23$ & $4.067^{\mathrm{a}} \pm 0.09$ & $2.106^{\mathrm{a}} \pm 0.07$ & $\begin{array}{c}4.086 \pm 0.01 \\
(54.5 \%)\end{array}$ \\
\hline $\mathrm{Cu} /\left(\mathrm{mg} \mathrm{g}^{-1}\right)-324.754 \mathrm{~nm}$ & $\begin{array}{c}0.078 \pm 0.04 \\
\quad(3.9 \%)\end{array}$ & $\begin{array}{c}0.153 \pm 0.01 \\
(15.3 \%)\end{array}$ & $\begin{array}{l}0.131 \pm 0.03 \\
(26.2 \%)\end{array}$ & $\begin{array}{c}0.022 \pm 0.03 \\
(17.6 \%)\end{array}$ & $\begin{array}{l}0.022 \pm 0.09 \\
\quad(10.0 \%)\end{array}$ \\
\hline $\mathrm{Fe} /\left(\mathrm{mg} \mathrm{g}^{-1}\right)-238.204 \mathrm{~nm}$ & $\begin{array}{c}6.182 \pm 1.64 \\
(34.3 \%)\end{array}$ & $\begin{array}{c}0.403 \pm 0.01 \\
\quad(4.0 \%)\end{array}$ & $\begin{array}{c}11.187 \pm 0.83 \\
(22.4 \%)\end{array}$ & $0.306^{\mathrm{a}} \pm 0.09$ & $\begin{array}{c}0.045 \pm 0.01 \\
\quad(1.5 \%)\end{array}$ \\
\hline $\mathrm{Mg} /\left(\mathrm{mg} \mathrm{g}^{-1}\right)-279.553 \mathrm{~nm}$ & $\begin{array}{c}15.011 \pm 3.17 \\
(15.0 \%)\end{array}$ & $\begin{array}{c}1.341 \pm 0.61 \\
(6.3 \%)\end{array}$ & $\begin{array}{c}0.908 \pm 0.07 \\
(18.2 \%)\end{array}$ & $\begin{array}{c}3.151 \pm 0.77 \\
(25.2 \%)\end{array}$ & $\begin{array}{c}2.178 \pm 0.21 \\
\quad(6.0 \%)\end{array}$ \\
\hline $\mathrm{Mn} /\left(\mathrm{mg} \mathrm{g}^{-1}\right)-257.610 \mathrm{~nm}$ & $\begin{array}{c}1.086 \pm 0.14 \\
(43.4 \%)\end{array}$ & $\begin{array}{c}0.0256 \pm 0.05 \\
\quad(51.2 \%)\end{array}$ & $\begin{array}{c}0.627 \pm 0.20 \\
(20.9 \%)\end{array}$ & $\begin{array}{c}0.066 \pm 0.02 \\
(2.6 \%)\end{array}$ & $\begin{array}{c}0.066 \pm 0.01 \\
\quad(8.8 \%)\end{array}$ \\
\hline $\mathrm{V} /\left(\mu \mathrm{g} \mathrm{g}^{-1}\right)-309.310 \mathrm{~nm}$ & $\begin{array}{l}5.14 \pm 0.06 \\
\quad(51.4 \%)\end{array}$ & $0.70^{\mathrm{a}} \pm 0.03$ & $0.52^{\mathrm{a}} \pm 0.05$ & $0.54^{\mathrm{a}} \pm 0.04$ & $0.54^{\mathrm{a}} \pm 0.04$ \\
\hline $\mathrm{Zn} /\left(\mathrm{mg} \mathrm{g}^{-1}\right)-213.857 \mathrm{~nm}$ & $\begin{array}{c}5.157 \pm 1.39 \\
(34.3 \%)\end{array}$ & $\begin{array}{c}0.352 \pm 0.58 \\
(70.4 \%)\end{array}$ & $\begin{array}{c}0.784 \pm 0.19 \\
(39.2 \%)\end{array}$ & $\begin{array}{c}0.226 \pm 0.08 \\
(1.5 \%)\end{array}$ & $\begin{array}{c}2.736 \pm 0.56 \\
(107.3 \%)\end{array}$ \\
\hline
\end{tabular}

${ }^{a}$ Content of the element not declared on the label of the supplement analyzed.

Table 5. Concentrations of $\mathrm{Ca}, \mathrm{Cu}, \mathrm{Fe}, \mathrm{Mg}, \mathrm{Mn}, \mathrm{Zn}, \mathrm{Cr}$ and $\mathrm{V}$, in multimineral and multivitamin preparations, after microwave digestion and analysis by ICP OES (mean \pm standard deviation, $\mathrm{n}=3,95 \%$ confidence level)

\begin{tabular}{|c|c|c|c|c|c|}
\hline Element & Product A & Product B & Product C & Product D & Product E \\
\hline $\mathrm{Ca} /\left(\mathrm{mg} \mathrm{g}^{-1}\right)-396.847 \mathrm{~nm}$ & $\begin{array}{c}158.52 \pm 2.12 \\
(97.9 \%)\end{array}$ & $\begin{array}{c}50.21 \pm 1.85 \\
(97.9 \%)\end{array}$ & $\begin{array}{c}44.56 \pm 0.94 \\
(89.1 \%)\end{array}$ & $<0.37$ & $\begin{array}{l}50.05 \pm 0.52 \\
(99.7 \%)\end{array}$ \\
\hline $\mathrm{Cr} /\left(\mu \mathrm{g} \mathrm{g}^{-1}\right)-267.716 \mathrm{~nm}$ & $\begin{array}{l}20.01 \pm 0.01 \\
\quad(80.0 \%)\end{array}$ & $<0.23$ & $6.52^{\mathrm{a}} \pm 0.01$ & $\begin{array}{c}14.03 \pm 0.01 \\
(56.0 \%)\end{array}$ & $\begin{array}{c}8.73 \pm 0.02 \\
(116.4 \%)\end{array}$ \\
\hline $\mathrm{Cu} /\left(\mathrm{mg} \mathrm{g}^{-1}\right)-324.754 \mathrm{~nm}$ & $\begin{array}{c}1.76 \pm 0.21 \\
(88.0 \%)\end{array}$ & $\begin{array}{c}0.86 \pm 0.08 \\
(86.0 \%)\end{array}$ & $\begin{array}{c}0.47 \pm 0.03 \\
(94.0 \%)\end{array}$ & $\begin{array}{c}0.152 \pm 0.03 \\
(124.0 \%)\end{array}$ & $\begin{array}{c}0.176 \pm 0.008 \\
(80.0 \%)\end{array}$ \\
\hline $\mathrm{Fe} /\left(\mathrm{mg} \mathrm{g}^{-1}\right)-238.204 \mathrm{~nm}$ & $\begin{array}{c}18.03 \pm 0.95 \\
(100.2 \%)\end{array}$ & $\begin{array}{c}8.41 \pm 0.90 \\
(84,1 \%)\end{array}$ & $\begin{array}{c}50.11 \pm 1.06 \\
(100.2 \%)\end{array}$ & $3.93^{\mathrm{a}} \pm 0.24$ & $\begin{array}{c}2.92 \pm 0.03 \\
(97.3 \%)\end{array}$ \\
\hline $\mathrm{Mg} /\left(\mathrm{mg} \mathrm{g}^{-1}\right)-279.553 \mathrm{~nm}$ & $\begin{array}{c}88.21 \pm 2.01 \\
(88.2 \%)\end{array}$ & $\begin{array}{c}18.87 \pm 1.83 \\
(89.01 \%)\end{array}$ & $\begin{array}{c}4.33 \pm 0.92 \\
(86.6 \%)\end{array}$ & $\begin{array}{c}11.90 \pm 0.12 \\
(95.2 \%)\end{array}$ & $\begin{array}{c}36.23 \pm 0.98 \\
(99.3 \%)\end{array}$ \\
\hline $\mathrm{Mn} /\left(\mathrm{mg} \mathrm{g}^{-1}\right)-257.610 \mathrm{~nm}$ & $\begin{array}{c}2.42 \pm 0.11 \\
(96.8 \%)\end{array}$ & $\begin{array}{c}0.44 \pm 0.03 \\
(88.0 \%)\end{array}$ & $\begin{array}{c}2.91 \pm 0.01 \\
(97.0 \%)\end{array}$ & $\begin{array}{c}2.82 \pm 0.09 \\
(112.8 \%)\end{array}$ & $\begin{array}{c}0.71 \pm 0.03 \\
(94.7 \%)\end{array}$ \\
\hline $\mathrm{V} /\left(\mu \mathrm{g} \mathrm{g}^{-1}\right)-309.310 \mathrm{~nm}$ & $\begin{array}{c}12.03 \pm 0.05 \\
(120.3 \%)\end{array}$ & $0.70^{\mathrm{a}} \pm 0.02$ & $0.60^{\mathrm{a}} \pm 0.04$ & $0.60^{\mathrm{a}} \pm 0.01$ & $0.60^{\mathrm{a}} \pm 0.05$ \\
\hline $\mathrm{Zn} /\left(\mathrm{mg} \mathrm{g}^{-1}\right)-213.857 \mathrm{~nm}$ & $\begin{array}{c}14.79 \pm 0.20 \\
(98.6 \%)\end{array}$ & $\begin{array}{c}0.49 \pm 0.06 \\
(98.0 \%)\end{array}$ & $\begin{array}{c}1.97 \pm 0.01 \\
(98.5 \%)\end{array}$ & $\begin{array}{c}15.85 \pm 0.07 \\
(105.7 \%)\end{array}$ & $\begin{array}{c}2.32 \pm 0.02 \\
(91.0 \%)\end{array}$ \\
\hline
\end{tabular}

a Content of the element not declared on the label of the supplement analyzed. 
$\mathrm{Mn}, \mathrm{Mo}, \mathrm{P}, \mathrm{Se}$ and $\mathrm{Zn}$ ) by inductively coupled plasma mass spectrometry (ICP MS) and electrothermal atomic absorption spectrometry (ET AAS), after dissolution in a high-pressure microwave system using concentrated nitric acid, and determined $\mathrm{Cr}$ in the range of 4.3 to $61.4 \mu \mathrm{g}$ per capsule. In this study, the concentration ranges $\left(\mu \mathrm{g} \mathrm{g}^{-1}\right)$ for $\mathrm{Cr}$ (4.0-17 and 9.0-34) were found after dissolution test and microwave digestion, respectively. These concentrations are below the value on the label of the analyzed products.

Abarca et al. ${ }^{38}$ developed a method to determine magnesium in multivitamin pharmaceutical preparation by FAAS after dissolution in acid medium. The concentration ranges $\left(\mathrm{mg} \mathrm{g}^{-1}\right)$ for $\mathrm{Mg}(0.292-0.325)$ were found. In this study, the $\mathrm{Mg}$ concentrations were below the value on the label of the products analyzed.

\section{Data evaluation using principal component analysis (PCA)}

The data provided by the manufacturer and obtained by procedures of dissolution and digestion were analyzed. Chromium and vanadium were not considered in the data processing since most of the manufacturers do not provide data on the concentration of these elements in the samples. The two first principal components (PC 1 and PC 2) describe $82.45 \%$ of the total variance. Table 6 shows the loadings of the variables on the first two principal components, and $\mathrm{Ca}, \mathrm{Mg}$ and $\mathrm{Cu}$ are the dominant variables in the first principal component (PC 1), which represents $60.07 \%$ of the total variance. Thus, these elements are the ones that contribute to the major variability among the manufacturers data (A, B, C, D and E) and the data obtained using dissolution procedures (D: green) and digestion in microwave (MW: red). Figure 3 (score plot) shows that some samples were separated.

Table 6. Loadings of the variables for PC 1 and PC 2

\begin{tabular}{lcc}
\hline Variable & PC 1 & PC 2 \\
\hline $\mathrm{Ca}$ & -0.949235 & 0.162548 \\
$\mathrm{Cu}$ & -0.896223 & 0.156348 \\
$\mathrm{Fe}$ & -0.373515 & -0.860084 \\
$\mathrm{Mg}$ & -0.886459 & 0.401356 \\
$\mathrm{Mn}$ & -0.682458 & -0.612836 \\
$\mathrm{Zn}$ & -0.713354 & 0.125161 \\
\hline Total variance / \% & 60.07 & 22.38 \\
\hline
\end{tabular}

The samples AD, BD, CD, DD and ED are grouped in a region that characterizes the lower availability of all nutrients relative to the indication of the manufacturer after 30 min of dissolution, in view of the low loadings for all

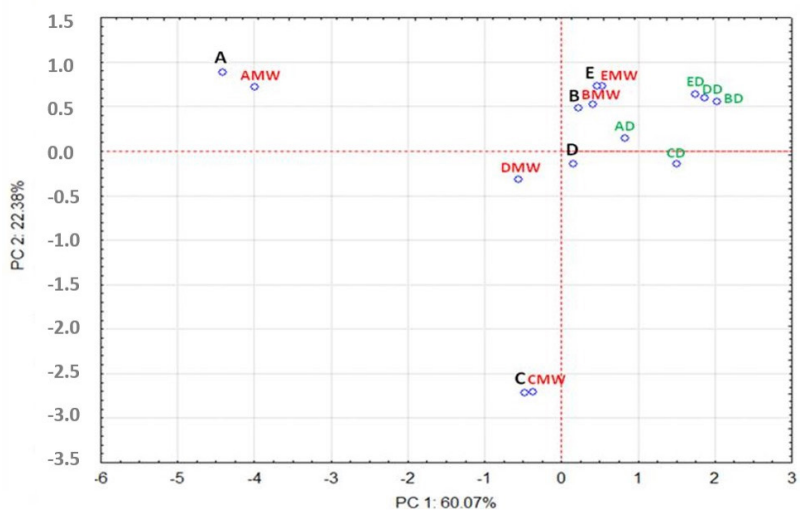

Figure 3. Score plot of the first two principal components.

elements and high scores of these samples. The proximity between the samples that were subjected to the digestion procedure in the microwave and the manufacturer samples in Figure 3 shows the similarity between them in terms of the concentrations of the investigated elements.

\section{Conclusions}

A dissolution test for macro and trace elements in multimineral and multivitamin preparations was validated using ICP OES. Dissolution profiles were obtained in $900 \mathrm{~mL}$ of $0.1 \mathrm{~mol} \mathrm{~L}{ }^{-1} \mathrm{HCl}$ medium at $37{ }^{\circ} \mathrm{C}$ baskets (USP apparatus 1), $75 \mathrm{rpm}$ stirring speed. This method demonstrated to be adequate to monitor the release of minerals in multimineral preparations, contributing to the quality control of these products. For most of the analyzed products, the release of analyte amounts was lower than those informed on manufacturers' labels. USP 34 indicates that not less than $75 \%$ of the elements described on the product label must be dissolved in $1 \mathrm{~h}$. Only the release of $\mathrm{Zn}$ met the recommendations. Total microwave digestion of the samples analyzed, followed by analysis by ICP OES, was used to compare the release of the analytes after $1 \mathrm{~h}$ of dissolution since it is a simple, fast and reliable method.

\section{Acknowledgments}

The authors are grateful for the financial support received from Fundação de Amparo à Pesquisa do Estado da Bahia (FAPESB) and Conselho Nacional de Desenvolvimento Científico e Tecnológico (CNPq), and also the research group of Biopharmaceutics and Drugs, Universidade Estadual da Bahia (UNEB).

\section{References}

1. Food and Drug Administration (FDA); Guidance for Industry: 
Dissolution Testing of Immediate Release Solid Oral Dosage Forms, Food and Drug Administration, available at http://www. fda.gov/downloads/drugs//guidances/ucm070237.pdf, accessed in April 2017.

2. Anand, O.; Yu, L. X.; Conner, D. P.; Davit, B. M.; AAPS J. 2011, 13, 328.

3. The United States Pharmacopeia, USP 34; United States Pharmacopeial Convention, Inc.: Rockville, USA, 2011.

4. Jambhekar, S. S.; Breen, P. J.; Drug Discovery Today 2013, 18, 1173.

5. Emani, J.; J. Pharm. Pharm. Sci. 2006, 9, 169.

6. Storpirtis, S.; Gonçalves, J. E.; Chiann, C.; Gai, M. N.; Biofarmacotécnica, $1^{\mathrm{a}}$ ed.; Guanabara Koogan: São Paulo, Brasil, 2011.

7. Cozzolino, S. M. F.; Biodisponibilidade de Nutrientes, $5^{\mathrm{a}}$ ed.; Manole: Barueri, Brasil, 2016.

8. Fairweather-Tait, S. J.; Food Chem. 1992, 43, 213.

9. Neves, D. B. J.; Caldas, E. D.; Regul. Toxicol. Pharm. 2015, $73,93$.

10. Zachariadis, G.; Olympiou, A. F.; J. Pharm. Biomed. Anal. 2008, 47, 541.

11. Zareba, S.; Hopkala, H.; J. Pharm. Biomed. Anal. 1996, 14, 1351.

12. Giacomino, A.; Abollino, O.; Casanova, C.; La Gioia, C.; Magi, E.; Malandrino, M.; Microchem. J. 2015, 120, 6.

13. Filipiak-Szok, A.; Kurzawa, W.; Szłyk, E.; J. Trace Elem. Med. Biol. 2015, 30, 54.

14. Trevizan, L. C.; Nobrega, J. A.; J. Braz. Chem. Soc. 2007, 18, 678.

15. Ghanjaoui, M. E.; Cervera, M. L.; El Rhazi, M.; Guardia, M.; Food Chem. 2011, 125, 1309.

16. Santos Junior, A. F.; Matos, R. A.; Andrade, E. M. J.; Santos, W. N. L.; Magalhães, H. I. F.; Costa, F. N.; Korn, M. G. A.; J. Braz. Chem. Soc. 2017, 28, 376.

17. Frentiu, T.; Ponta, M.; Darvasi, E.; Frentiu, M.; Cordo, E.; Food Chem. 2012, 134, 2447.

18. Avula, B.; Wang, Y. H.; Duzgoren-Aydin, N. S.; Khan, I. A.; Food Chem. 2011, 127, 54.

19. Krejkova, A.; Kahoun, D.; Chernohorsky, T.; Pouzar, M.; Food Chem. 2006, 98, 171.

20. Soriano, S.; Pereira Netto, A. D.; Cassella, R. J.; J. Pharm. Biomed. Anal. 2007, 43, 304.
21. Karpinska, J.; Kulikowska, M.; J. Pharm. Biomed. Anal. 2002, 29, 153.

22. Pharmacopoeia Brasileira, $5^{\text {a }}$ ed.; Agência Nacional de Vigilância Sanitária (ANVISA), Brasília, Brasil, 2010.

23. Agência Nacional de Vigilância Sanitária (ANVISA); Dispõe sobre a realização dos Estudos de Equivalência Farmacêutica e de Perfil de Dissolução Comparativo, Resolution - RE No. 31, 11 August, 2010, available at http://portal.anvisa. gov.br/documents/33880/2568070/res0031_11_08_2010. pdf/5e157d15-d3d5-4bb9-98db-5667e4d9e0c8, accessed in April 2017.

24. International Conference on Harmonisation (ICH); Validation of Analytical Procedures: Text and Methodology Q2 (R1), available at https://www.ich.org/fileadmin/Public_Web_Site/ ICH_Products/Guidelines/Quality/Q2_R1/Step4/Q2_R1__ Guideline.pdf, accessed in April 2017.

25. Krampitz, P. D.; Barnes, K. W.; Atom. Spectrosc. 1998, 19, 43.

26. Montaser, A. R.; Golightly, D. W.; Inductively Coupled Plasma in Analytical Atomic Spectrometry, $2^{\text {nd }}$ ed.; VCH: New York, USA, 1996.

27. Silva, J. C. J.; Baccan, N.; Nobrega, J. A.; J. Braz. Chem. Soc. 2003, 14, 310.

28. Pravina, P.; Sayaji, D.; Avinash, M.; IJRPBS 2013, 4, 659.

29. Grober, U.; Schmidt, J.; Kisters, K.; Nutrients 2015, 7, 8199.

30. Krejpcio, Z.; Pol. J. Environ. Stud. 2001, 10, 399.

31. Aoki, T.; JMAJ 2004, 47, 365.

32. Abbaspour, N.; Hurrell, R.; Kelishadi, R.; J. Res. Med. Sci. 2014, 19, 164.

33. Soetan, K. O.; Olaiya, C. O.; Oyewole, O. E.; Afr. J. Food Sci. 2010, 4, 200.

34. Gruzewska, K.; Michno, A.; Pawelczyk, T.; Bielarczyk, H.; J. Physiol. Pharmacol. 2014, 65, 603.

35. Vidyavati, S. D.; Sneha, A.; Katti, S. M.; IJHBR 2016, 4, 18.

36. Roohani, N.; Hurrell, R.; Kelishadi, R.; Schulin, R.; J. Res. Med. Sci. 2013, 18, 144.

37. Soltyk, K.; Lozak, A.; Ostapczuk, P.; Fijalek, Z.; J. Pharm. Biomed. Anal. 2003, 32, 425.

38. Abarca, A.; Canfranc, E.; Sierra, I.; Marina, M. L.; J. Pharm. Biomed. Anal. 2001, 25, 941.

Submitted: February 3, 2017 Published online: April 7, 2017 